\title{
Proximal Femoral Epiphysis Anatomy in Chilean Population. Orthopedic and Forensic Aspects
}

\author{
Anatomía del Epífisis Proximal del Fémur en la Población Chilena. \\ Aspectos Traumatológicos y Forenses \\ "Horacio Osorio; "Karl Schorwer; ${ }^{* *}$ César Coronado; ${ }^{* * * *}$ Javier Delgado \& ${ }^{* * * * *}$ Pedro Aravena
}

OSORIO, H.; SCHORWER, K.; CORONADO, C.; DELGADO, J. \& ARAVENA, P. Proximal femoral epiphysis anatomy in Chilean population. Orthopedic and forensic aspects. Int. J. Morphol., 30(1):258-262, 2012.

SUMMARY: From a biomechanical standpoint, bone geometry and density are factors correlated to the bone resistance of the femur when supporting body weight, with geometric parameters like the diameter of the femoral head and neck, the length of the femoral neck, and the femoral neck angle as determinant factors in the incidence of hip fractures, which increase in frequency and seriousness in osteoporotic patients. In Chile, morphometric data that contributes to relating the anatomy of the proximal epiphysis of the femur as an associated factor in hip fractures does not exist; likewise, there are no anthropometric indexes that may contribute to the forensic sciences. The purpose of this study is to establish average measurements of the proximal epiphysis of the femur in the adult Chilean population. Descriptive Study. The proximal epiphyses of 81 dry adult femurs were analyzed (44 right and 37 left bones), measuring the following parameters: length of the femoral neck (LN), femoral neck angle (FNA), circumference of the femoral head (CH) and circumference of the femoral neck $(\mathrm{CN})$. The statistical relationship between the measurements and the side of each sample was analyzed (t-test $\mathrm{p}=0.05)$. The average lengths were $\mathrm{LN}=3.59 \mathrm{~cm}( \pm 0.43 \mathrm{~cm}) ; \mathrm{FNA}=124.17^{\circ}\left( \pm 6.37^{\circ}\right), \mathrm{CH}=14.34 \mathrm{~cm}( \pm 1.27 \mathrm{~cm})$ and $\mathrm{CN}=9.7 \mathrm{~cm}$ $( \pm 0.87 \mathrm{~cm})$. No significant differences between the left and right sides were found. Average numbers were obtained for the anatomy of the proximal femoral epiphysis from a sample in the Chilean population. With the data obtained, we propose to carry out anatomoclinical, epidemiologic and forensic studies in this population.

KEY WORDS: Anatomy; Femur head; Femur neck; Hip fractures.

\section{INTRODUCTION}

From a biomechanical standpoint, bone geometry and density are factors that correlate with bone resistance of the femur when supporting body weight. Geometric parameters, like the length of the femoral neck and the femoral neck angle (Malavolta et al., 2003; Pulkkinen et al., 2004), along with the diameter of the femoral neck and cortical thinning in the neck of the femur (Black et al., 2008), are determining factors in the incidence of hip fractures, which increase in frequency and seriousness in osteoporotic patients (Gnudi et al., 2004).

Hip fractures are common in elderly patients, and it is an important cause for disability, a current problem in public health, in a population that progressively grows older. The causes are multifactorial, but the major contributing factor is the reduction in the resistance of the proximal epiphysis of the femur, due mainly to osteoporosis, both primary and secondary (Orwoll et al., 2009).
Fractures in the femoral neck have been vastly studied, and from their classification, it has been derived that there are stable and unstable fractures, divided in 4 groups that range from incomplete, to complete and displaced (Garden, 1961).

There are differences in the propensity to proximal femoral fractures in individuals of specific populations (Zang et al., 2010), presenting data that suggests that white individuals have a comparatively higher propensity than Asians and those of African decent (population $\geq 65$ years old) (Marshall et al., 2008).

In Chile, the studies that currently exist only determine that the increment in the rates of hip fracture is associated with growing older (Valdivia et al., 1996; Mautalen \& Pumarino, 1997). However, there is no available data that contributes

* Department of Normal Anatomy. School of Medicine. Universidad de Concepción, Chile.

** Departamento de Morfofunción, Facultad de Medicina, Universidad Diego Portales, Chile.

**** Institute of Locomotor System. School of Medicine. Universidad Austral de Chile, Chile.

***** Institute of Anatomy, Histology and Pathology. School of Medicine. Universidad Austral de Chile, Chile. 
to relating the anatomy of the proximal femoral epiphysis as a factor that is associated with hip fractures. Likewise, there are no anthropometric indexes that may contribute to the forensic sciences. The objective of this study is to describe the morphometry of the proximal epiphysis of the femur in Chilean adults from the Bio-Bio Region, in Chile.

\section{MATERIAL AND METHOD}

A descriptive study. Dry human femurs were analyzed in the laboratory of Human Anatomy at Universidad de Concepción in 2009. Adult bones without sex distinctions were included in the study. Bones with visible abnormalities, signs of degenerative osteoarthritis, areas with decalcification or loss of tissue due to manipulation were excluded. The analyzed parameters were the following (Fig. 1):

Circumference of the femoral head $(\mathrm{CH})$ : largest diameter of the femoral head.

Circumference of the femoral neck $(\mathrm{CN})$ : diameter of the femoral neck measured from the midpoint between the base of the femoral head and the intertrochanteric line.

Length of the femoral neck (LN): distance between the inferior region of the femoral head and the intertrochanteric line.

Femoral Neck Angle (FNA): angle between the major axis of the body, with the major axis of the femoral neck.

The lengths were measured with a 8" Mitutoyo caliper. For the circumferences, a metric tape in millimeters and for the FNA angle an standard goniometer was used. All measurements were recorded by the same observer.

Averages, standard deviations, and the minimum and maximum values were determined for all measurements. To verify the presence of differences in the variables under study between left and right femurs, we used a t-test with a significance level of 5\%. The data was tabulated with the Microsoft Excel 2003 software, and analyzed with the statistical program STATA 10.0 (StataCorp LP. USA).

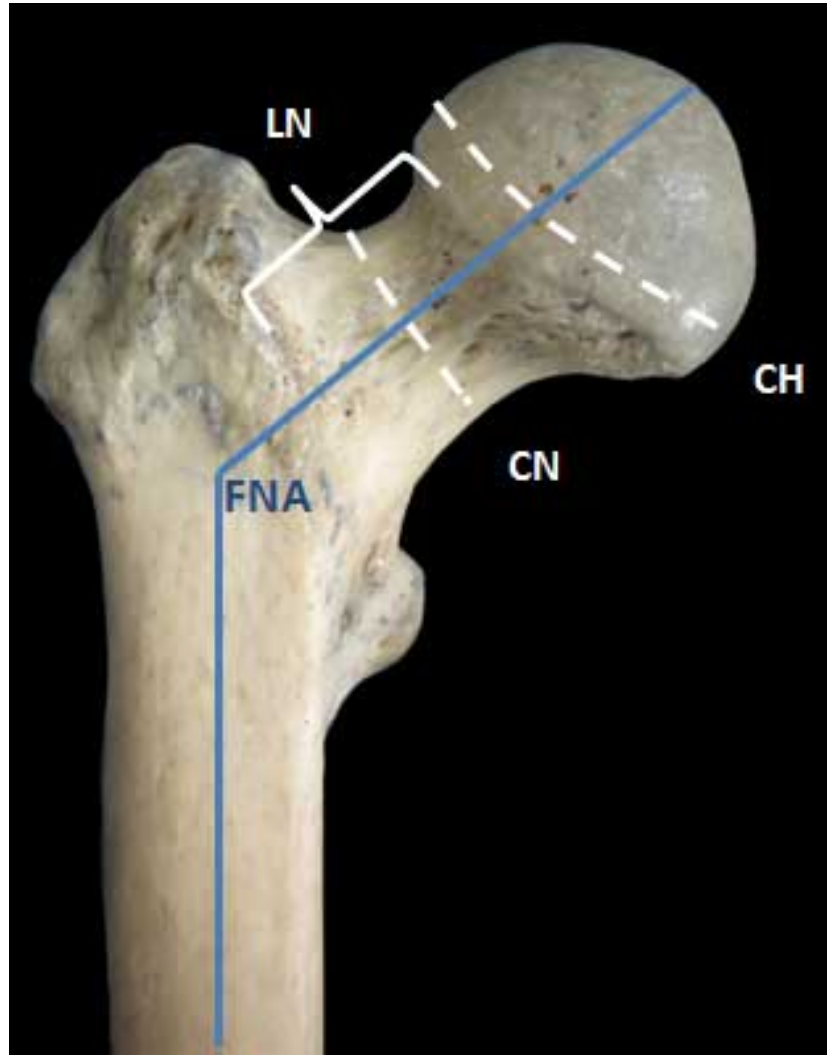

Fig. 1. Diagram of measurements of the proximal femoral epiphysis. $\mathrm{CH}$ : Circumference of the femoral head; $\mathrm{CN}$ : Circumference of the femoral neck; LN: Length of the femoral neck; FNA: Femoral Neck Angle.

\section{RESULTS}

In total, 81 human femurs were selected, 44 right and 37 left bones. The average lengths were $\mathrm{LN}=3.59 \mathrm{~cm}( \pm 0.43$ $\mathrm{cm}) ; \mathrm{FNA}=124.17^{\circ}\left( \pm 6.37^{\circ}\right), \mathrm{CH}=14.34 \mathrm{~cm}( \pm 1.27 \mathrm{~cm})$ and $\mathrm{CN}=9.7 \mathrm{~cm}( \pm 0.87 \mathrm{~cm})$. No statistically significant differences were found in the circumference of the head $(\mathrm{p}=0.27)$, in the circumference of the neck $(\mathrm{p}=0.83)$, the FNA $(\mathrm{p}=0.77)$, and in the length of the neck $(\mathrm{p}=0.40)$, between left-side and right-side femurs (Table I).

Table I. Arithmetic means, standard deviations $( \pm$ ) and minimums and maximum values (min-max) of the circumference of head and neck, the length of the neck and angle of the femoral neck in centimeters, and the statistical relationship between right $(n=44)$ and left $(\mathrm{n}=37)$ femurs.

\begin{tabular}{|c|c|c|c|c|c|c|}
\hline \multirow[t]{2}{*}{ Measures } & \multirow[t]{2}{*}{$\overline{R i g h t}( \pm)$} & \multirow[t]{2}{*}{$\overline{\text { Left }( \pm)}$} & \multicolumn{2}{|c|}{ Min-Max } & \multirow[b]{2}{*}{$\operatorname{Total}( \pm)$} & \multirow[b]{2}{*}{$p$ value } \\
\hline & & & Right & Left & & \\
\hline Circumference femoral head & $14.49(0.94)$ & $14.17(1.56)$ & $12.4-16.1$ & $8.13-16.9$ & $14.34(1.27)$ & 0.27 \\
\hline Circumference of femoral neck & $9.72(0.81)$ & $9.68(1)$ & $8-11.2$ & $7.6-11.1$ & $9.7(0.89)$ & 0.83 \\
\hline Femoral neck length & $3.55(0.41)$ & $3.64(0.44)$ & $2.65-4.6$ & $2.85-5.3$ & $3.59(0.43)$ & 0.77 \\
\hline Angle of the femoral neck & $124.3^{\circ}\left(6.14^{\circ}\right)$ & $123.9^{\circ}\left(6.71^{\circ}\right)$ & $113^{\circ}-144^{\circ}$ & $113^{\circ}-145^{\circ}$ & $124.17^{\circ}\left(6.37^{\circ}\right)$ & 0.40 \\
\hline
\end{tabular}




\section{DISCUSSION}

In this descriptive study, the proximal epiphyses of 81 dry femurs were analyzed; no significant differences in the size of the circumference of the femoral head, the size and thickness of the femoral neck, and the angle of the femoral neck were found between right-side and left-side samples. These results are concordant with the analysis done by Anderson \& Trinkaus (1998), which determined that there are few bone patterns that define variations between the dominant leg and its counterpart. Studies in Brazilian femurs (Caetano et al., 2007) present, on average, a $5^{\circ}$ in the FNA angle. Likewise, Toogood et al. (2009) found a femoral neck angle of $129.23^{\circ}\left( \pm 6.24^{\circ}\right)$ in 375 femurs, coming from white and African races from the Cleveland Museum, USA; additionally, anteversion in the femoral head was found in femurs of more than 50 years of age.

Prasad et al. (1996) determined in India an average of $126.8^{\circ}$ in the diaphysis-neck angle $\left( \pm 3.1^{\circ}\right)$ and an average length of the neck of $28.4 \mathrm{~mm}( \pm 4.5 \mathrm{~mm})$ and a femoral head diameter of $41.2 \mathrm{~mm}( \pm 3.8 \mathrm{~mm})$ which, differing from our results, did find statistically significant differences between the gender of the dried bones, though not from one side to the other. All these angles are within acceptable orthopedic ranges, and no femurs were found presenting coxa valga or vara.

Other anatomo-clinical studies undertaken through anteroposterior hip x-rays garner other results. In 150 healthy patients, Lecerf et al. (2009) obtained an average FNA of $129^{\circ}\left( \pm 6^{\circ}\right)$. Likewise, Umer et al. (2010) obtained similar results in the Pakistani population, where the femoral neck angle was on average $130.3 \mathrm{~mm}( \pm 6.1 \mathrm{~mm})$. Calis et al. (2004) observed in x-rays of Turkish female patients that the width of the femoral neck was $35 \mathrm{~mm}$, along with an angle of $128.9^{\circ}$.

To observe the exactness and reliability of x-ray studies, Rubin et al. (1992) compared measurements obtained from anteroposterior hip x-rays and CT scans in 32 femurs. There, the average angle of the femoral neck was $122.9^{\circ}\left( \pm 7.6^{\circ}\right)$, finding an average distortion of $0.9 \mathrm{~mm}$ $( \pm 1.4 \mathrm{~mm})$ between measurements done through $\mathrm{x}$-rays, and those done with CT scans.

Morphological data for the proximal epiphysis of the femur are essential in anthropological, forensic and clinic milieus. It is known that the ethnicity, heredity, climate and nutritional conditions of a population affect the length of the long bones and the height of a person. Calculating femoral length from the dimensions of the proximal end of the femur has great potential for application in physical anthropology, medical jurisprudence and forensic identification of an individual (Prasad et al.). The FNA in the femur is zero at the time of birth, and develops in relationship with growth. Its development is linked to verticalization and learning to walk, and it reached definite values at age 8 , closely related with the age of the subject and the length of the femur (Tadieu \& Damsin, 1997). This is particularly evident in cases of diminished or lack of weight-bearing during development, as in cases of children with congenital hip dysplasia (Anderson \& Trinkaus).

The use of these statistical calculations with logistic regressions allows obtaining the length of the femur, and therefore, of the individual, from proximal femoral fragments. The angle of the femoral neck relates significantly with the length of the neck, but not with the diameter of the femoral head. In general, short people will have shorter femurs, shorter femoral necks, and smaller FNA, and thus, a more oblique femoral neck. Therefore, it is justified to say that the taller the individual, the more pronounced the femoral neck will be (Isaac at al., 1997), within normal orthopedic parameters.

The physical characteristics of the bone, like bone mass, size and geometry, microarchitecture, bone remodeling and previous fractures of the proximal epiphysis of the femur, allow predicting the risk for hip fractures in different populations (Valdivia, 1999). It has been established that the thickness in the femoral neck coincides with diminished production of endosteal bone, having as a result a loss of bone density (Bone Mineral Density $\mathrm{BMD}$ ), and a rise in sub periosteal bone, secondary to the production generated at growth (Dinçel et al., 2008). In a retrospective study, El-Kaissi et al. (2005) demonstrated that Caucasian postmenopausal women with hip fractures have a longer length and axis of the femoral neck, compared to women without fractures, determining that, independent of their age, height and bone density, the risk of hip fracture increases by $24 \%$ with every one millimeter increase in the thickness of the femoral neck. Calis et al. obtained a similar result in Turkish women, where the angle and width of the femoral neck were significantly greater in patients with hip fractures.

In Chile, the incidence of hip fracture increases with age, $90 \%$ of them occurring in patients over 50 . The mean age for cases is 80 , with 2 to 3 times more incidence in women. Most frequent are femoral neck and trochanteric fractures, representing $90 \%$ of documented cases (Muñoz 
et al., 2008). In 1996, at seven public hospitals in Santiago, Chile, $47 \%$ of reported fractures were on the left side, observing that rates increase strongly, influenced by age and gender factors (Valdivia et al.).

Sapunar et al. (2003) make an exhaustive analysis of the Mapuche ethnic influence in the incidence of hip fractures. In it, the clear predominance of the female gender is noteworthy, as is the significantly less portion of Mapuche individuals among patients with fractures. It shows that Mapuche ethnicity is a protective factor for proximal femur fractures (OR: 0.37; IC: 95\% 0,177-0.77 y $\mathrm{p}=0.0076)$, compared with non-Mapuche patients residing in urban sectors. This may be attributed to higher levels of physical activity and hard labor, and a lower incidence of smoking in this population. The existing relationship between osteoporosis and the thickening of the femoral neck, femoral morphology and its geometric disposition continue to be a matter of study, becoming progressively more interesting in the context of an increasingly older population pyramid. Likewise, there is an interest in modifying bone architecture with drugs that inhibit osteoclastic activity, but still fractures with increasingly complex treatments continue to occur, reason why the study of bone architecture and its understanding as a biological entity and not merely a structural one still are relevant topics.

Average values in the anatomy of the proximal epiphysis of the femur in the Chilean population were obtained. No significant differences were found between left and right bones. The data garnered may contribute to the analysis of causal factors for hip fractures in Chile, which as has been analyzed, may determine predictive values in the study of at-risk populations. In addition, it may also contribute with morphometric data about a bone structure in the superior limb, which may by useful in the analysis of forensic bone remains in Chilean population.

OSORIO, H.; SCHORWER, K.; CORONADO, C.; DELGADO, J. \& ARAVENA, P. Anatomía de epífisis proximal de fémur en la población chilena. Aspectos traumatológicos y forenses. Int. J. Morphol., 30(1):258-262, 2012.

RESUMEN: Desde un punto de vista biomecánico, la geometría y la densidad ósea son factores correlacionados con la resistencia del hueso del fémur al apoyar el peso corporal, con los parámetros geométricos, como el diámetro de la cabeza femoral y el cuello, la longitud del cuello del fémur, y el ángulo del cuello femoral factores determinantes en la incidencia de fracturas de cadera, que aumentan en frecuencia y gravedad en los pacientes con osteoporosis. En Chile, no existen datos morfométricos que relacionen la anatomía de la epífisis proximal del fémur como un factor asociado a las fracturas de cadera ni índices antropométricos que pueden contribuir a las ciencias forenses. El propósito de este estudio es establecer las medidas promedio de la epífisis proximal de fémur en población adulta chilena. Estudio Descriptivo. Se analizaron la epífisis proximal de 81 fémures adultos secos (44 derechos y 37 izquierdos), midiendo los siguientes parámetros: longitud del cuello femoral (LC), ángulo cérvico-diafisiario femoral (ACD), circunferencia de la cabeza femoral $(\mathrm{CCa})$ y circunferencia del cuello femoral $(\mathrm{CCu})$. Se analizó la relación estadística de las medidas con el lado de cada muestra (test Chi cuadrado p:0,05) Las longitudes promedios fueron LC: $3,59 \mathrm{~cm}( \pm 0,43 \mathrm{~cm}) ; A C D: 124,17^{\circ}\left( \pm 6,37^{\circ} \mathrm{cm}\right) ; \mathrm{CCa}: 14,34 \mathrm{~cm}( \pm 1,27 \mathrm{~cm})$ y $\mathrm{CCu}: 9,7 \mathrm{~cm}( \pm 0,87 \mathrm{~cm})$. No se encontraron diferencias significativas entre el lado derecho e izquierdo. Los resultados proponen la necesidad de realizar estudios anatomo-clínicos y epidemiológicos actualizados en población chilena donde la geometría de la epífisis proximal del fémur se incluya dentro del análisis.

PALABRAS CLAVE: Anatomía; Cabeza femoral; Cuello femoral; Fractura de cadera.

\section{REFERENCES}

Anderson J. Y. \& Trinkaus, E. Patterns of sexual, bilateral and interpopulational variation in human femoral neck-shaft angles. J. Anat., 192:279-85, 1998.

Black, D. M.; Bouxsein, M. L.; Marshall, L. M.; Cummings, S. R.; Lang, T. F.; Cauley, J. A.; Ensrud, K. E.; Nielson, C. M. \& Orwoll, E. S. Proximal femoral structure and the prediction of hip fracture in men: a large prospective study using QCT. $J$. Bone Miner. Res., 23(8):1326-33, 2008.

Caetano, E. B.; Serafim, A. G. \& Padoveze, E. H. Study of the Collo-diaphyseal Angle of the Femur of Corpses in the
Anatomy Department of the PUC-SP Medical School. Int. J. Morphol., 25:285-8, 2007.

Calis, H. T.; Eryavuz, M. \& Calis, M. Comparison of femoral geometry among cases with and without hip fractures. Yonsei Med. J., 45:901-7, 2004.

Dinçel, V. E.; Sengelen, M.; Sepici, V.; Cavus sog`lu, T. \& Sepici, $\mathrm{B}$. The association of proximal femur geometry with hip fracture risk. Clin. Anat., 21:575-80, 2008.

El-Kaissi, S.; Pasco, J. A.; Henry, M. J.; Panahi, S.; Nicholson, J. 
G.; Nicholson, G. C. \& Kotowicz, M. A. Femoral neck geometry and hip fracture risk: the Geelong osteoporosis study. Osteoporos Int., 16:1299-303, 2005.

Garden, R. S. Low-angle fixation in fractures of the femoral neck. J. Bone Joint Surg. Br., 43-B:647-63, 1961.

Gnudi, S.; Malavolta, N.; Testi, D. \& Viceconti, M. Differences in proximal femur geometry distinguish vertebral from femoral neck fractures in osteoporotic women. Br. J. Radiol., 77(915):219-23, 2004.

Isaac, B.; Vettivel, S.; Prasad, R.; Jeyaseelan, L. \& Chandi, G. Prediction of the Femoral Neck-Shaft Angle From the Length of the Femoral Neck. Clin. Anat., 10:318-23, 1997.

Lecerf, G.; Fessy, M. H.; Philippot, R.; Massin, P.; Giraud, F.; Flecher, X.; Girard, J.; Mertl, P.; Marchetti, E. \& Stindel, E. Femoral offset: Anatomical concept, definition, assessment, implications for preoperative templating and hip arthroplasty. Orthop. Traumatol. Surg. Res., 95:210-9, 2009.

Malavolta, N., Frigato, M., Mulé, R. and Ripamonti, C. Femoral neck morphology differentiates femoral neck from vertebral osteoporotic fracture. Reumatismo, 55(2):93-7, 2003.

Marshall, L. M.; Zmuda, J. M.; Chan, B. K.; Barrett-Connor, E.; Cauley, J. A.; Ensrud, K. E.; Lang, T. F. \& Orwoll, E. S. Race and Ethnic Variation in Proximal Femur Structure and BMD Among Older Men. J. Bone Miner. Res., 23(1):121-30, 2008.

Mautalen, C. \& Pumarino, H. Epidemiology of osteoporosis in South America. Osteoporos. Int., 7 Suppl 3:S73-7, 1997.

Muñoz, G. S.; Lavanderos, F. J.; Vilches, A. L.; Delgado, M. M.; Carcamo, H. K.; Passalaqua, S. H. \& Guarda, M. M. Fractura de cadera. Cuad. Cir., 22:73-81, 2008.

Orwoll, E. S.; Marshall, L. M.; Nielson, C. M.; Cummings, S. R.; Lapidus, J.; Cauley, J. A.; Ensrud, K.; Lane, N.; Hoffmann, P. R,; Kopperdahl, D. L. \& Keaveny, T. M. Finite element analysis of the proximal femur and hip fracture risk in older men. $J$. Bone Miner. Res., 24(3):475-83, 2009.

Pulkkinen, P.; Partanen, J.; Jalovaara, P. \& Jämsä, T. Combination of bone mineral density and upper femur geometry improves the prediction of hip fracture. Osteoporos. Int., 15(4):274-80, 2004.

Prasad, R.; Vettivel, S.; Jeyaseelan, L.; Isaac, B. \& Chandi, G. Reconstruction of Femur Length From Markers of Its Proximal End. Clin. Anat., 9:28-33, 1996.

Rubin, P. J.; Leyvraz, P. F.; Aubaniac, J. M.; Argenson, J. N.; Estève, P. \& de Roguin, B. The morphology of the proximal femur. A three-dimensional radiographic analysis. J. Bone Joint Surg. Br. 74:28-32, 1992.
Sapunar, J.; Bravo, P.; Schneider, H. \& Jiménez, M. Is Mapuche ethnicity a risk factor for hip fracture in aged?. Rev. Med.Chil., 131:1135-41, 2003.

Toogood, P. A.; Skalak, A. \& Cooperman, D. R. Proximal Femoral Anatomy in the Normal Human Population. Clin. Orthop. Relat. Res., 467:876-85, 2009.

Tardieu C. \& Damsin J. P. Evolution of the angle of obliquity of the femoral diaphysis during growth--correlations. Surg. Radiol. Anat., 19:91-7, 1997.

Umer, M.; Sepah, Y. J.; Khan, A.; Wazir, A.; Ahmed, M. \& Jawad, M. U. Morphology of the proximal femur in a Pakistani population. J. Orthop. Surg., 18:279-81, 2010.

Valdivia, C. G. Epidemiología de la osteoporosis. Boletín de la Escuela de Medicina, Pontificia Universidad Católica de Chile, 28:1-2, 1999.

Valdivia, G.; Giaconi, J.; Arteaga, E.; Pumarino, H.; Gajardo, H. \& Villarroel, L. Fractura de la cadera: estudio de casos y controles en la región Metropolitana I. Rev. Med. Chile, 124:18997, 1996.

\section{Correspondence to: \\ Pedro Aravena \\ Campus Isla Teja s/n \\ Valdivia \\ CHILE}

Phone: +56-63-221205

Email: paravena@uach.cl

Received: 21-10-2011

Accepted: 24-12-2011 